\title{
WHERE THE OPTIMAL BALANCE IS BETWEEN \\ PUBLIC AND PRIVATE JOBS: A QUALITATIVE STUDY OF GRADUATES FROM UNIVERSITY OF JAFFNA
}

\author{
Dilogini.K* \& Y.Thasika** \\ *Department of Marketing, Faculty of Management studies and Commerce, \\ University of Jaffna \\ dilo.kuru@yahoo.com \\ **Department of Human Resource management, Faculty of Management \\ studies and Commerce, University of Jaffna \\ thasiyoges@gmail.com
}

\begin{abstract}
Throughout the qualitative study, researchers examined how graduates are demanding jobs to settle an optimal balance between public and private jobs. Findings are based on in-depth interviews with recently and earlier passed out graduates from University of Jaffna. In this study, researchers revealed how a job of graduates is finding an optimal balance, engaged in public and private jobs. Data were collected from 25 recently passed out and 25 earlier passed out graduates. First, researchers explored the situational and beneficial demands placed on those public and private jobs, along with the optimal balance that often results from those demands. Researchers then specified new model that reforms those job demands. To produce results, researchers developed a theoretical model of optimal balance between public and private jobs for graduates. Key findings of this study are the gaining of consciousness regarding to job selection underpinning stimuli and discover the balancing points between private and public jobs through inductive codes developed by researchers in this qualitative exploratory study.
\end{abstract}

Keywords: Demands, Graduates, Jobs, Optimal balance and Qualitative study

\section{Introduction}

Graduates choose their career in public sector and private sector while they are studying or after they finish their degree. However, their career path selection in both fields are influenced by so many factors such as job security, salary package and other allowances, pension and EPF scheme, nature of the job, parents influences etc. In this study, researchers would like to analyze optimal balance regarding selection of career path decided by graduates. 
If the graduates decide to go to either government job or private job while they were studying in university, there will be no confusion after the graduation regarding the job preference in government or private. But students who study the degrees without specific ambition will face the confusion problem after they finish the degree. Some of the graduates prefer government job that will be given to them by periodically where as some graduates prefer the private jobs because of high competitiveness and time delay to get government jobs as well as salary and other high benefits in private sector. The most parents still highly prefer to get government job to their children because they feel that government jobs have lifelong security as well as good respect from society. One the other hand, young and energetic graduates initially work in private organization and change their job to government because of work pressure and longer working time in private organization.

\section{Research Gap and Research Problem}

Lyons, Duxbury and Higgins (2006) have done a study of comparison of the values and commitment of private sector, public sector, and parapublic sector employees. The differences of work values of employees in different sector are analyzed on that study. Researchers stated that there is a need for qualitative research to fully understand and explain the nature and root causes of these differences. Bellante and Link (1981) have done a study "Are public sector workers more risk averse than private sector workersfi" Researchers noted that the reason behind why there is tendency to seek employment in public sector is individual job security associated with public jobs.

However, there should be optimal balance among these both jobs. Both people who work in government organization and private organization argue pros and cons in both careers. There is an argument in between the government and private jobs still exist. Moreover, qualified degree holders struggle much more about job preferences than other people with other education qualifications. In this regard, they are searching enhanced equilibrium while they accepting their jobs in public as well as private sectors. There are lacks of researches in related to this field in Sri Lanka; especially in Jaffna district. That is a major knowledge gap to this study. Therefore, this concept should be analyzed and developed a job equilibrium model by researchers. The problem statement is "where the optimal balance is between public and private jobsfi"

Therefore, the final output of this research will add value to knowledge and literature in the area of job preferences and job choices. The contribution of this study to the 
researcher is the acquisition of depth knowledge regards to job sectors selection stimuli as well as application of balancing model between private and public. It will be beneficial source of reference to researchers, graduates, academies as well as job seekers. It will also be functional guide to management and employees of the Private and Public sectors. They will get to know the application of job balancing model and what can be done to improve the job balancing system as well as concern and offer the job preference factors of employees. Finally, to the University, this research looks for to add the part of knowledge like it would be the basis for consequent studies in related area of topics.

\section{Literature Review}

The findings from Box (1999) as well as results from Van Gramberg and Teicher (2000) help to make an argument on the new managerialism in the public sector. Motivational profile, which is similar to private sector managers at a lower management level, is used by public sector managers (Buelens \& Van den Broeck, 2007). There are two sectors in every country. If we take into consideration of both sectors, both are equally essential to country for the development and growth of country. Public Sector and Private Sector mutually contribute to the country in several ways such as production of goods, providing services, controlling the country, ruling the country etc (Kumari \& Pandey, 2011). Lewis and Frank (2002) noted that Endorsement of public-service values and rewards are not directly organized by public-service job. Both sectors are needed to the country development and relationship between both sectors is identical and unique to country (Lyons, Duxbury \& Higgins, 2006).

Both government and private jobs, which provide more benefits to workers, are mostly related to work effort rather than payment and promotion chances (Frank \& Lewis, 2004). Su and Bozeman (2009) noted that the People who are working in private sector are ready to change their sector to government but not to nonprofit sector. Due to this reason, aged work forces are increased in government sector. Public sector should develop promotional activities as private sector consists to get the higher performance due to the positive effects on motivation (Frank \& Lewis, 2004). In 1992, Rosenfeld stated that if one person leaves from his or her job, another person will leave his or her job to fulfill that left job. Likewise, the job is fulfilled cyclically as chain until a new person enters to fulfill the job. Frank and Lewis (2004) noted that if there is no sectoral differences in the motivational effects of high pay and advancement effects, either (a) rewards and benefit do not that much affect performance in private sector than public sector, (b) these kind of motivational tools have low impact on work 
performance in both sector or (c) these variables are taken in this study to analyze the degree of their effects.

As well as security, the thinking about social worth can also play major role in selecting to work in the public sector. The motive of feeling of social usefulness is major stimuli along with public sector employees (Dixit, 2002). In 2006, Millward, Houston, Brown and Barrett have done a study and examined the possible causes of gender segregation and its connection to skills deficiencies in the UK labor market via investigating young people's perceptions about work and their preferences for jobs. Hyder (2007) has done a study on the titled of "preference for public sector jobs and wait unemployment: A micro data analysis" and stated that the public job preference indicating that fringe benefits and work conditions are conceivably more important considerations.

\section{Methodology}

Qualitative analysis can sound almost like "listening to your gut" and indeed many qualitative analysts would argue that gut feelings have their place in the process. That does not mean, however, that it is not a rigorous approach. Indeed, it can consume much more time and energy than quantitative analysis (Patton, 1990). The strength of qualitative research is its ability to provide complex textual descriptions of how people experience a given research issue, it provides information about the "human" side of an issue- that is, the often contradictory behaviors, beliefs, opinions, emotions \& relationships of individuals, although findings from qualitative data can often be extended to people with characteristics similar to those in the study population (Natasha Mack, 2005). So in this research researchers have used qualitative method to explore the optimal balance of private and government jobs.

\section{Population}

The population for this study includes passed out graduates in University of Jaffna. Data were collected from recently passed out and earlier passed out graduates.

\section{Sampling Technique}

Purposive sampling is mainly popular in qualitative studies. Purposive sampling, also referred to as judgment, selective or subjective sampling is a non-probability sampling method that is characterised by a deliberate effort to gain representative samples by including groups or typical areas in a sample. The researcher relies on 
his/her own judgement to select sample group members. In purposive sampling, researcher has sufficient knowledge of topic to select sample of experts and subjects that are chosen in this sampling method according to the type of the topic (Patton, 1990). The main advantage of purposive sampling is that to reach the sample of subjects with specific characteristics. Researchers have selected this sampling method for this study. In the qualitative study there are no closely defined rules for sample size (Baum 2002). Sampling in qualitative research usually depends on small numbers with the objective of studying in depth and detail (Patton 1990). The sample is derived purposefully rather than randomly (Reed et al. 1996). In this way researchers selected only 25 recently passed out and 25 earlier passed out graduates from University of Jaffna.

\section{Instruments}

In-depth interview often described as a form of conversation (Saunders et al., 2015). So that researchers have used this method to identify the factors on optimal balance between public and private jobs. In-depth interviews are flexible in that they can be presented in a number of ways and there is no specific format to follow. However, like all evaluation results, justification and methodology of the study should be provided, as well as any supporting information. In-depth interview data may stand alone or be included in a larger evaluation report.

This research study fully concentrated on in-depth interviews by using preset questions based on primary interview questions as open- ended question format. Interview questions are; "As recently passed out graduate, why would you prefer public jobsfi", "As recently passed out graduate, why would you prefer private jobsfi", "As earlier passed out graduate, why would you prefer public jobsfi" and "As earlier passed out graduate, why would you prefer private jobsfi"

\section{Data Analysis Methods}

The outlined process enabled a systematic and logic step-by-step approach for the analysis of the qualitative data and allowed the researcher to go beyond mere descriptive, comparative and explanatory ends to discover the rationale and motivation for responses (Thietart, 2007). And also, there are several ways to take qualitative data such as; field notes, audio recordings \& transcripts. In this way, researchers conducted in depth interviews and those interviews were digitally recorded, translated \& transcribed (Bryman \& Bell, 2011). The entire transcribed text and interview notes were thoroughly read at first to obtain overall and comprehensive 
thoughts of the content and context before the abstraction process of coding began where units of meaning are identified or labeled (Henning et al., 2004). The transcribed text was arranged manually in meaningful themes and categories by the researchers. The coding process for the field notes and transcripts consisted of three steps described by Thietart (2007) namely: open coding, axial coding and selective coding.

In this research, inductive codes were developed by the researchers by directly examining the data. The researchers have done 1st coding through line-by-line analysis and identified important concepts from transcribed interviews, and then the researchers have done axial coding as a 2nd coding, finally the researchers have found the concepts/themes that emerged from data. Analysis outlined in the preceding illustrated in Figure 1 and coding steps and concepts/themes are presented here below in the tables.

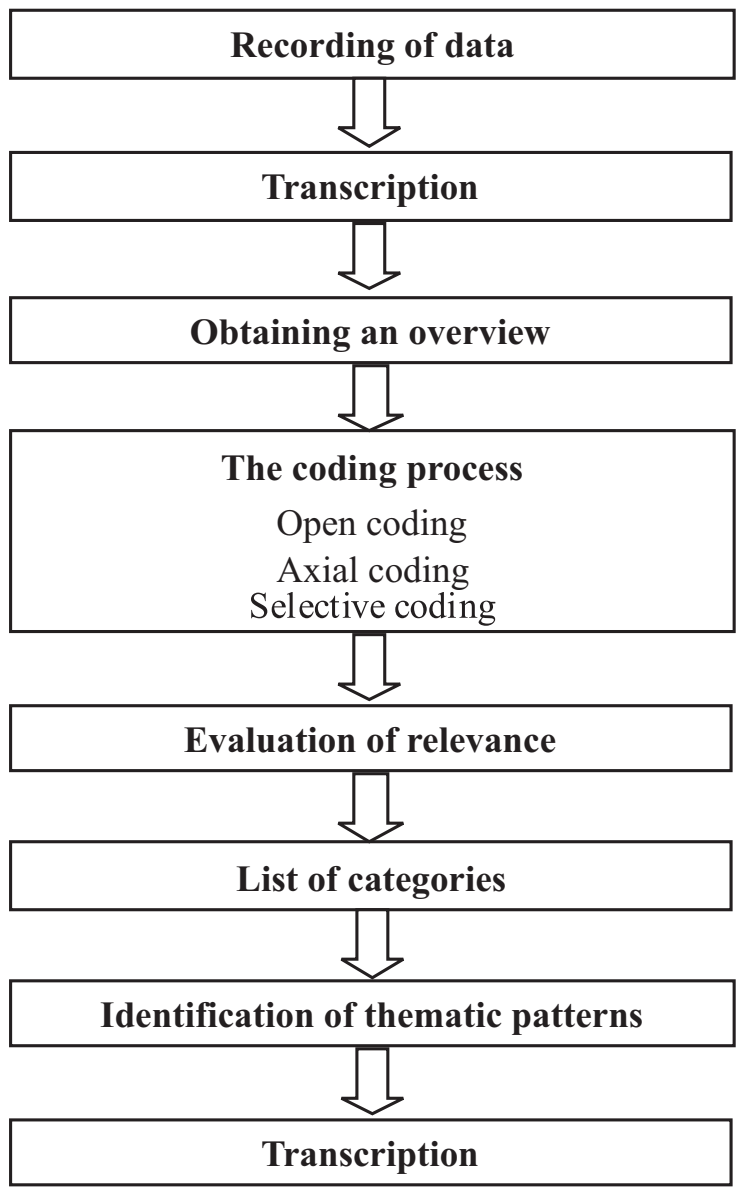

Figure 1: The qualitative analysis process 


\section{Reliability and Validity of Analysis}

There are some criteria for reliability and validity of qualitative research, such as;

- Credibility (in place of internal validity), that is, the extent that the constructions adequately represent the participant's reality.

- Transferability (in place of external validity), that is, an adequately and thickly described account so that those who wish to transfer the implications to another context can do so with an adequate data base.

- Dependability (in place of reliability), that is, the data is internally coherent.

- Confirm ability (in place of objectivity), that is, the extent to which the theoretical implications are grounded in the data (Guba and Lincon, 1981).

Therefore, in this study, all the interviews were translated, transcribed and findings and sent back to the respondents in order to determine the accuracy of the interview findings.

\section{Data Analysis and Conclusion}

\section{DataAnalysis}

IQ1: As recently passed out graduate, why would you prefer public jobsfi

Table 1:

\begin{tabular}{lll}
\hline \multicolumn{1}{c}{$\mathbf{1}^{\text {st }}$ coding } & \multicolumn{1}{c}{$\mathbf{2}^{\text {nd }}$ coding } & \multicolumn{1}{c}{ Concepts } \\
\hline 1. monthly target & 1. difficulties & 1. Prestige \\
2. higher work pressure & 2. Job security & value \\
3. with the difficulties & 3. respect & 2. Job security \\
4. my ambition from childhood & 4. definitely go & \\
5. job security for life time & & \\
6. more respect from society & & \\
7. I don't like this private job & & \\
8. Social concern & & \\
9. Respectfully & & \\
10. I'll definitely go there & & \\
\hline
\end{tabular}


IQ2: As recently passed out graduate, why would you prefer private jobsfi

Table 2:

\begin{tabular}{|c|c|c|}
\hline $1^{\text {st }}$ coding & $2^{\text {nd }}$ coding & Concepts \\
\hline $\begin{array}{l}\text { 1. higher benefits } \\
\text { 2. adopted to luxury life } \\
\text { 3. government salary is not enough } \\
\text { 4. monthly expenses } \\
\text { 5. benefits from government are } \\
\text { 6. I prefer the private sector } \\
\text { 7. we can get higher benefits } \\
\text { 8. based on performance } \\
\text { 9. enjoy our present life } \\
\text { 10. due to high income from private } \\
\text { 11. Lifestyle }\end{array}$ & $\begin{array}{l}\text { 1. higher benefits } \\
\text { 2. adopted to luxury } \\
\text { life } \\
\text { 3. government salary } \\
\text { is not enough } \\
\text { 4. enjoy our present } \\
\text { life } \\
\text { 5. to high income } \\
\text { from private }\end{array}$ & $\begin{array}{l}\text { 1. Attractive salary } \\
\text { 2. Luxurious } \\
\text { lifestyle }\end{array}$ \\
\hline
\end{tabular}

IQ3: As earlier passed out graduate, why would you prefer public jobsfi Table 3:

\begin{tabular}{|c|c|c|}
\hline $1^{\text {st }}$ coding & $2^{\text {nd }}$ coding & Concepts \\
\hline $\begin{array}{l}\text { 1. higher stress } \\
\text { 2. longer working time } \\
\text { 3. with stress free } \\
\text { 4. lot of difficulties } \\
\text { 5. working as teacher } \\
\text { 6. joined in government teaching } \\
\text { 7. pension scheme } \\
\text { 8. after the retirement } \\
\text { 9. comparing with private job } \\
\text { 10. because of higher stress } \\
\text { 11. if have an opportunities in } \\
\text { government job } \\
\text { 12. think about after the age of } 65 \\
\text { 13. Don't like to depend on others } \\
\text { when old a ge periods }\end{array}$ & $\begin{array}{l}\text { 1. higher stress in } \\
\text { private job } \\
\text { 2. stress free } \\
\text { 3. pension scheme } \\
\text { 4. after the retirement }\end{array}$ & $\begin{array}{l}\text { 1. Stress - free } \\
\text { 2. Lifetime } \\
\text { retirement } \\
\text { benefits }\end{array}$ \\
\hline
\end{tabular}


IQ4: As earlier passed out graduate, why would you prefer private jobsfi Table 4

\begin{tabular}{|c|c|c|}
\hline $1^{\text {st }}$ coding & $2^{\text {nd }}$ coding & Concepts \\
\hline $\begin{array}{l}\text { 1. spending time with family } \\
\text { 2. retirem ent benefits } \\
\text { 3. other benefits provided by } \\
\text { my company } \\
\text { 4. still work in private sector } \\
\text { 5. many opportunities } \\
\text { 6. work in private sector } \\
\text { 7. If we perform well } \\
\text { 8. promoted quickly } \\
\text { 9. can become good position } \\
\text { within short period } \\
\text { 10. we can spend more } \\
\text { 11. Big amount of money at our } \\
\text { retirement time }\end{array}$ & $\begin{array}{l}\text { 1. retirement benefits } \\
\text { 2. more bene fits } \\
\text { 3. many opportunities } \\
\text { 4. promotions } \\
\text { 5. motivations }\end{array}$ & $\begin{array}{l}\text { 1. High level of } \\
\text { motivation } \\
\text { 2. Lump sum } \\
\text { retirement } \\
\text { benefits }\end{array}$ \\
\hline
\end{tabular}

Coding tables (Source: Authors constructed)

In this paper, there are some gaps to be filled in respect of job preferences and selections among public and private jobs. This paper represents the original contribution regarding optimal balance between public and private jobs. Harry Wolcott (1999) mentioned that one of the main problems in qualitative study is to provide details where a small amount of information exists. Normally, qualitative research means; investigation in to a problem or situation which provides insights to the researcher. There are some stimuli of public as well as private job preferences identified by researchers. The research results state that the optimal balance between them. Researchers have identified different stimuli. Such as; prestige value, job security, attractive salary, luxurious lifestyle, stress - free, lifetime retirement benefits, lump sum retirement benefits and high level of motivation.

"I got many opportunities to work in private sector. But I would like to work in public sector because there is a pension scheme after the retirement and job security for life time and also there is still more respect from society to government job comparing with private job"

\section{(Earlier passed out graduate)}

Through the in-depth interviews researchers have identified some supporting and opposing factors regarding public and private job preferences from recently and earlier passed out graduates. According to the above statement, the respondent stated 
about lifetime benefits from public job. On the other hand another respondent sated that,

"I'm working in private sector now. I face a lot of difficulties in my job comparing with government job such as monthly target, lack of spending time with family and higher work pressure. But due to higher benefits from my job, I adopted to luxury life with car and other benefits provided by my company. If I go to government job, government salary is not enough to spend my current monthly expenses. Therefore, I still work in private sector with the difficulties"

(Earlier passed out graduate)

Based on this earlier passed out graduate's statement, the preferences are mainly based on luxurious life style. Therefore, some graduates appreciate the higher benefits from private job with some difficulties. Still the different points of view are existing on the subject of preferences of public and private jobs.

"I prefer the private sector to work because benefits from government are very low. But in private job, we can get higher benefits such as good salary, medical covers, insurance policy, bonus, incentives"

(Recently passed out graduate)

\section{Conclusion}

Overall, researchers have found out eight stimuli for job preferences of jobs among graduates from University of Jaffna. Stimuli for public jobs are; prestige value, job security, stress - free and lifetime retirement benefits. At the same time, stimuli for private jobs are; attractive salary, luxurious lifestyle, high level of motivation and lump sum retirement benefits. Apart from that, prestige value, job security, attractive salary and luxurious lifestyle are concerned by recently passed out graduates. On the other hand, stress-free, lifetime retirement benefits, high level of motivation and lump sum retirement benefits are concerned by earlier passed out graduates respectively public and private jobs (presented here above in four tables). The current situation is an argumentative; graduates are having two view points on public and private jobs. They want to recognize the optimal balance between them. Finally, researchers have developed a new model (figure 2) by using identified concepts such as stimuli of public job preferences and stimuli of private job preferences of recently and earlier passed out graduates. These stimuli could be identified and diagrammed; it would then be possible to better understand why graduates have chosen in certain manner and what the motivating forces would entail for passed out graduates' job adaptation. 


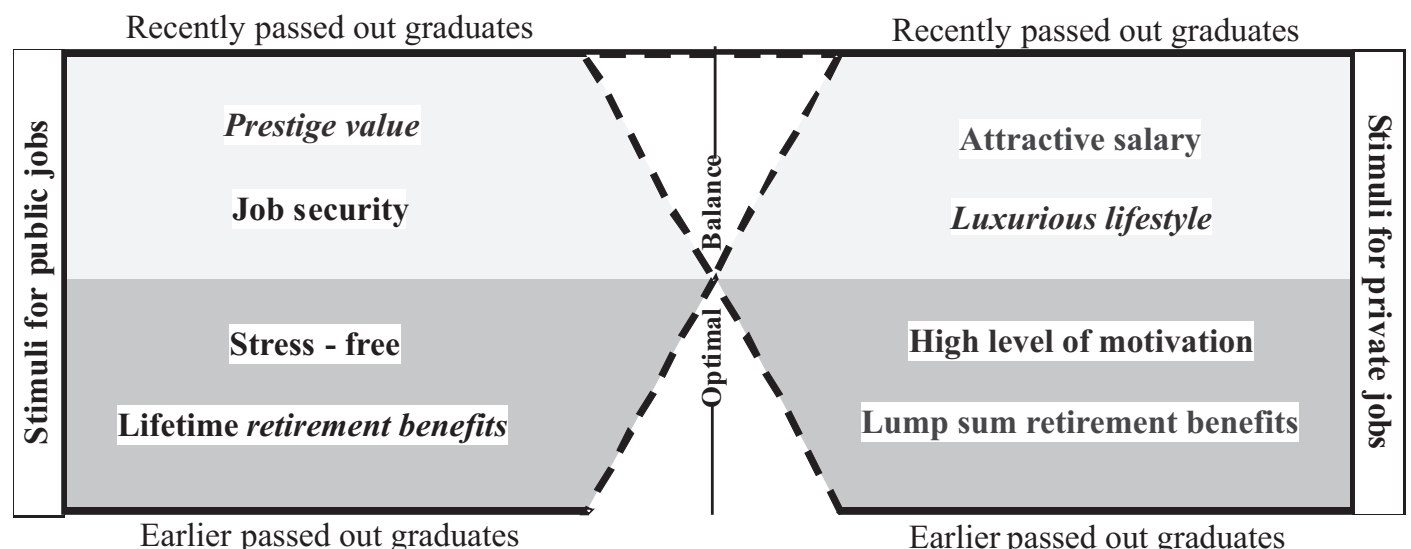

Figure 2: Optimal balance between public and private jobs

These forces compel an under or over identification of stimuli. Hence, the model presents the integration of stimuli of public jobs or stimuli of private jobs at hand or separating stimuli of public jobs from the stimuli of private jobs, and they are fairly stable with the model. Researchers took up this logic in order to create a balancing model of graduates' job adaptation as summarized in Figure 2. At the top of the model, there are stimuli of public and private sectors' attentions stated by early passed out graduates. On the other hand, there are stimuli of public and private sectors' attentions stated by recent passed out graduates shown in the bottom of the model. These stimuli represent motives of graduate's job adaptation in related field. They can all happen simultaneously. Researchers propose that optimal balance is reached when these forces are in equilibrium. Wherein, the overlap between stimuli for public job and stimuli for private job is either scarce or excessive. The study on optimal balance, optimal individuality and related constructs has been fruitful. That is a graduate's benefits from selecting the desired equilibrium between pressures for selection, job adaptation, uniqueness, distinction and satisfaction. Graduates can take action to balance for fluctuations in the middle of other stimuli in the job preference that create an imbalance.

Although, an important limitation is that it focuses on selected respondents which consist only twenty five recent and twenty five earlier passed out graduates from University of Jaffna by using qualitative exploratory method. Therefore, future researchers can do their study in this same field by using quantitative methodology or mixed methods. The outcome of this research shows another limitation is that this research relied only on the perception of passed out graduates from University of Jaffna. Therefore, the knowledge from this study might be a little bit biased by the recently and earlier passed out graduates' particular viewpoints toward the issues in 
this study. Thus, future researches would include lecturers, parents and other members in the working environment.

There are some notable facts to the future researcher such as immediate passed out graduates who are willing to work in public sector due to prestige value and job security, may change their preference to work in private sector due to high level of motivation and lump sum retirement benefits likewise, immediate passed out graduates who are willing to work in private sector due to attractive salary and luxurious lifestyle, may change their preference to work in public sector due to stressfree and lifetime retirement benefits. Future researchers can find out and analysis the reasons of these changes of job preferences through qualitative exploratory study and also, they can test this new model empirically while job seeker can use this model when they decide their career decisions after the graduation.

\section{References}

Bellante, D., \& Link, A. N. (1981). Are public sector workers more risk averse than private sector workersfi. ILR Review, 34(3), 408-412.

Box, R. C. (1999). Running government like a business: Implications for public administration theory and practice. The American Review of Public Administration, 29(1), 19-43.

Bryman, A., \& Bell, E. (2011). Ethics in business research. Business Research Methods.

Buelens, M., \& Van den Broeck, H. (2007). An analysis of differences in work motivation between public and private sector organizations. Public administration review, 67(1), 65-74.

Dixit, A. (2002). Incentives and organizations in the public sector: An interpretative review. Journal of human resources, 696-727.

Frank, S. A., \& Lewis, G. B. (2004). Government employees: Working hard or hardly workingfi. The American Review of Public Administration, 34(1), 36-51.

Guba, E. G., \& Lincoln, Y. S. (1981). Effective evaluation: Improving the usefulness of evaluation results through responsive and naturalistic approaches. JosseyBass.

Henning, E., Van Rensburg, W., \& Smit, B. (2004). Finding your way in qualitative research (pp. 19-22). Pretoria: Van Schaik. 
Hyder, A. (2007). Preference for public sector jobs and wait unemployment: A micro data analysis (No. 2007: 20). Pakistan Institute of Development Economics.

Kumari, G., \& Pandey, K. M. (2011). Job satisfaction in public sector and private sector: A comparison. International Journal of Innovation, Management and Technology, 2(3), 222.

Lewis, G. B., \& Frank, S. A. (2002). Who wants to work for the governmentfi. Public administration review, 62(4), 395-404.

Lyons, S. T., Duxbury, L. E., \& Higgins, C. A. (2006). A comparison of the values and commitment of private sector, public sector, and parapublic sector employees. Public administration review, 66(4), 605-618.

Millward, L., Houston, D., Brown, D., \& Barrett, M. (2006). Young people's job perceptions and preferences. Department of Trade and Industry.

Natashamack, cynthiawoodsong, kathleenmacqueen, gregguest,emilynamey,(2005), "qualitative research methods: a data collector's field guide", research triangle park, north carolina: family health international.

Patton, M.Q., 1990. Qualitative evaluation and research methods . SAGE Publications, inc.

Rosenfeld, R. A. (1992). Job mobility and career processes. Annual Review of Sociology, 18(1), 39-61.

Saunders, B., Kitzinger, J., \& Kitzinger, C. (2015). Anonymising interview data: Challenges and compromise in practice. Qualitative Research, 15(5), 616-632.

Su, X., \& Bozeman, B. (2009). Dynamics of sector switching: Hazard models predicting changes from private sector jobs to public and nonprofit sector jobs. Public Administration Review, 69(6), 1106-1114.

Thiétart, R. (Ed.). (2007). Doing management research: A comprehensive guide. London: Sage Publications

Van Gramberg, B., \& Teicher, J. (2000). Managerialism in local government-Victoria, Australia. International Journal of Public Sector Management, 13(5), 476-492.

Wolcott, H. F. (2002). Ethnographyfi Or educational travel writing. Ethnography and schools: Qualitative approaches to the study of education, 27-48. 